also a rather specialized chapter on laboratory diagnosis. The second half of the book gives brief accounts of other virus infections of the respiratory tract. There are full chapters on atypical pneumonia and febrile catarrh unassociated with the influenza viruses while further short chapters deal with the common cold, $Q$ fever, psittacosis and P.U.O.

Finally, there is discussion on prevention and treatment of these virus infections with a description of the present state of immunization and chemotherapy.

This book is well reproduced and has up to date references after each chapter. It can be warmly recommended to all those who wish to bring up to date their knowledge of these extremely common respiratory conditions.

\section{A GUIDE TO OBSTETRICS IN GENERAL PRACTICE}

By W. C. W. Nixon, M.D., F.R.C.S., F.R.C.O.G., and E. B. HICKSON, M.R.C.S., L.R.C.P., D.R.C.O.G. Pp. 301, with 35 illustrations. London: Staples Press, Ltd. r 953 . 30s.

Here at long last is a thoroughly practical textbook of obstetrics. Such a book has long been needed for those doctors who are practising obstetrics without any specialist experience. All the frills of obstetric theory are left out. Furthermore, the statements which are so often found in textbooks which are handed down from one edition to the next, and which seldom seem to have any basis in practice, are ignored. A good example of this omission is the fact that I could find no mention of the treatment of extended legs in a breech delivery. Instead, one is asked to leave the baby alone until the umbilicus is showing, which is sound advice.

I particularly like the chapter on the desirability of pregnancy. which answers many questions on the chances of abnormalities occurring.

Included at the end of the book are chapters on the National Health Service, notifications and child adoption.

The book is not lavishly produced, nor are there any illustrations. This no doubt has helped to keep the cost down to 30s., which is cheap for present-day textbooks. It is certainly worth farz more.

T.C.F.E.

\section{THE PRACTICAL MANAGEMENT OF PAIN} IN LABOUR

By W. D. WYLIE, M.A., M.B., M.R.C.P. F.F.A.R.C.S. Pp. xii +148 , with 42 illustra tions. London: Lloyd-Luke, Ltd. $1953 \overrightarrow{\mathrm{D}}$ I8s. $6 \mathrm{~d}$.

This is a comprehensive yet concise book which will be of the greatest use to the anaesthetist, the obstetrician and the general practitioner alike. It iswritten in a very pleasing style with excellent illus $\vec{\omega}$ trations which are well grouped to synchronize with? the text, photographs and illustrations of anaesthetif apparatus occupy a section of their own at the end of the appropriate chapter.

Dr. Wylie speaks with authority as it is obvious to the reader that he has personal knowledge of altw the procedures described.

Despite the title the author has managed to in $-\mathrm{N}$ clude all the important anaesthetic procedures associated with obstetrics and the text has been so arranged that each procedure has been dealt with in? its logical sequence. This, and the high quality of production, makes this book all the more easy tof read.

A.J.H.H.

\section{PATHOLOGY OF TUMOURS}

By R. A. WILlis, D.Sc., M.D., F.R.C9P and Edition. Pp. xiv + I,05 I, with 500 illustra tions. London: Butterworth \& Co. I953 $£ 44$ s.

It is a pleasure to welcome the second edition of this- the most authoritative book on tumours in English. Like the other books by Professor Willis it is written in a clear and forthright style which is most refreshing. The work is based on his own experience and the reader is never left in doubt as to the author's meaning or viewpoint. It is. however, not a book for the ordinary student (pres? or post-graduate) but for the specialist in morbio anatomy.

D.M.P.

\section{NOTICE OF SPECIAL INTEREST TO SUBSCRIBERS: \\ "WHY NOT HAVE YOUR COPIES OF THIS JOURNAL BOUND INTO YEARLY VOLUMES?"}

\begin{abstract}
Arrangements have now been made to have the twelve monthly issues fully bound in dark green pin head cloth, lettered in gilt on spine with name of Journal, Volume Number and year, complete with index at front, 17s. 6d. per Volume, post free. A limited number of out of print journals are available to bind into volumes and make your library complete. Price on application giving details of issues required to complete back volumes.
\end{abstract}

THE

MedICINE

\author{
60 PORTLAND PLACE, LONDON, $W .1$
}

WHY NOT

HAVE YOUR

JOURNALS BOUND? 